\title{
Factor Structure of Individual Consequences for Teleworking Professionals
}

\author{
John Campbell \\ ANU College of Business and Economics \\ The Australian National University \\ john.campbell@anu.edu.au \\ Jon Heales \\ UQ Business School \\ University of Queensland
}

\section{Abstract}

Despite the increasing popularity of telework, little is known about individual outcomes that arise particularly for teleworking professionals. We build on earlier research by examining the conceptual constructs of individual consequences from telework. We initially categorized consequences identified in the extant literature into five areas. However, this model was not supported by confirmatory factor analysis of survey data collected from 250 teleworking accounting professionals. Subsequent exploratory factor analysis revealed a more complex sixfactor structure relating to (1) Effectiveness; (2) Self-assurance; (3) Working with Others; (4) Work Pressure; (5) Professional Image; and (6) Physicality. The results extend our understanding of latent constructs underlying telework by professional knowledge workers, and provide a basis for further refinement of our model based on empirical research and theoretical development.

Keywords: Telework, individual consequences, structural analysis

\section{Introduction}

The incidence of telework in professional service occupations is significant and continues to increase. A recent USA survey showed that seventy-six percent of the organisations surveyed allowed some employees to routinely work a portion of their regular work hours from home (Matos and Galinsky, 2014). As telework gains wider acceptance, practitioners and researchers need to understand better the underlying factors involved in telework.

Much of the existing research has only examined the advantages and disadvantages of telework and has not adopted the necessary broader research perspectives required to examine the deeper issues and the roles played by affected stakeholders. Furthermore, much of the research undertaken to date focused on organizational aspects so there is a need to balance this with research that better examines the personal/individual factors involved. We believe it is important to examine drivers of telework from an individual's perspective because the individual forms 50 percent of the relationship between telework and the organization, and ultimately makes the decision whether or not to telework. Individuals should also be aware of the factors involved that affect them as teleworkers, and our work seeks to help inform them. We do know that telework introduces distinct discontinuities from traditional face-to-face work environments, and that these discontinuities have been shown to bring about significant changes in communication patterns (Campbell, 2006; Rafaeli and Ravid, 2003). The motivation for this paper is to explore the factor structure of individual impacts associated with telework and of their association with telework practice in professional occupations.

The following section briefly discusses existing research frameworks developed for studying telework. 


\section{Theories of Telework Adoption}

Economic factors such as increased productivity and cost reductions are frequently cited as the main organizational drivers for telework adoption (see Hill et al., 1998; Watad and DiSanzo, 2000). While economic considerations are generally important drivers for the adoption of workplace technologies, it is also important to consider the legal, ethical, and human issues, particularly for professional roles (Davenport and Pearlson, 1998). Telework is also seen as a strategy to help ensure business continuity in the face of a pandemic or other disaster (The Telework Coalition, 2009). The establishment of sound working relationships between teleworkers, non-teleworkers, and managers is critical for a successful telework program (Guimaraes and Dallow, 1999; Reinsch, 1997).

Alternative conceptual models for telework adoption and utilization have been proposed. Some of these models focus on the relationship between different telework task configurations and employee attitudes and behaviours (Feldman and Gainey, 1997; Shamir and Salomon, 1985, Hunton and Harmon, 2004). Others have proposed a supply/ demand approach (Gray, 1997), or emphasized the relationship between different telework practices and organizational outcomes (Bélanger and Collins, 1998).

Siha and Monroe (2006) proposed a research model following an extensive review of the telework/telecommuting literature. For Siha and Monroe, competition and government regulation provide the impetus for organizations to consider telework strategies. Consequently, their model follows a top-down perspective beginning with a strategic organizational dimension that is influenced by the regulatory and competitive environment within which an organization operates. This strategic view is further moderated by the level of support from both employees and management, and is reliant on the deployment of appropriate technologies to adequately support telework activities (Siha and Monroe, $2006 \mathrm{p}$. 466).

According to Siha and Monroe (2006), the success of an organizational telework program is measured in terms of regulatory compliance; positive environmental impact; productivity increases and cost reductions; and worker satisfaction. However there are several substantive limitations with this model. First, telework adoption in some organizations may not follow a rational decision-making process. For example, telework may evolve over an extended period of time from the work practices of only a few individuals. Second, the criteria for successful telework programs are reliant on stakeholder perspectives that are not well-defined and likely to change over time. Third, there is a lack of focus on the human challenges associated with telework particularly in how work practices are altered and how these might infringe on family and personal life.

In contrast, the Telework Behavioural Model (TBM) developed by Hunton and Harmon (2004) focuses on psychological effects, individual outcomes, and organizational consequences. In the TBM, the link between human motivation and telework choices (whether to telework, where to telework, and how often to telework) is mediated by the range of telework options allowed in organizational policy (Hunton and Harmon, 2004). Hunton and Harmon argue that telework choices have psychological properties (cognitions and affects) that in turn influence individual outcomes such as more or less work, family conflict, reduced commute time, scheduling flexibility, and other individual-level effects. Telework choices can also impact organizations in ways that will require a modification of behaviour. For example, an organization's telework policy may result in work practices that reduce real estate costs and staff turnover, or alternatively reduce customer service and workplace collegiality. Consequently, organizations will need to monitor and modify their telework policies with the aim of accruing the most value while minimizing negative outcomes. Like the Siha and Monroe model, little is offered by the TBM for those organizations where telework practices are slowly evolving through processes other than a formal organizational policy, or those situations where individuals are able to negotiate or expropriate a unique telework regime. 
Gajendran and Harrison (2007) put forward a theoretical framework, based on psychological mediators and individual outcomes, to direct their meta-analysis of the telecommuting literature. Their framework identified three proximal consequences (perceived autonomy, work-family conflict, and supervisor/co-worker relationship quality), and five distal consequences (job satisfaction, performance, turnover intention, role stress, and perceived career prospects). While the framework provided a useful basis for analysing the literature, it contained a number of inconsistencies in how the proximal and distal consequences were selected and categorised. For example, it can be argued that an individual's perceptions of performance and role stress (both identified as distal consequences) are in fact proximal outcomes. This is especially relevant for professional knowledge workers. Also, it can beargued that other proximal factors are missing such as professional quality of work performed, and the personal costs incurred when teleworking.

More recently, Campbell and McDonald (2009) proposed a Systems-Based Telework Framework (SBTF) that presented a dynamic view of the evolution of telework practices. Their model built on elements from Hunton and Harman (2004) and Siha and Monroe (2006) and drew these perspectives together to reflect three fundamental structural elements of telework practice within organizations: the motivation for adopting telework (Telework Drivers), telework activities and processes (Telework Processes), and the outcomes and consequences of telework activities (Telework Outcomes). These structural elements are all highly interrelated. The SBTF is also a meta-model with the potential to accommodate a range of philosophical perspectives in telework research from investigations on technology appropriation (Orlikowski, 2000) through to critical studies on the micro-political processes associated with the performance and management of work (Deetz, 2005).

\section{Research Approach}

Because the objective of our research was to examine the latent constructs underlying telework for professional knowledge workers, we first examined the literature to identify potential constructs for testing. We analysed the SBTF (employee impact), Gajendran and Harrison's (2007) meta-model (proximal consequences), and the TBM (personal outcomes) approaches from the perspective of direct consequences for professional teleworkers. The nature of individual outcomes, as described in the SBTF and TBM models, is at this stage somewhat uncertain and unspecified. While Gajendran and Harrison's (2007) framework identified three proximal outcomes (perceived autonomy, work-family conflict, and relationship quality), it can be argued that other important constructs are missing (e.g., professional quality and personal cost of remote work), or that some proximal outcomes have been misclassified as distal consequences (e.g., performance and role stress). However, we used these models as the starting point for specifying proximal consequences for teleworking professionals.

Earlier studies have also examined a range of work and home-related outcomes for teleworkers including expectations and perceived consequences (Maruyama and Tietze, 2012), impact on work-life balance (Maruyama et al., 2009), and differences in perceived outcomes for workers from different work locations (Morganson et al., 2010). In contrast our study is not causal in approach, but addresses a more fundamental examination of how individual outcomes from telework are structured. From the literature we identified five outcome themes for teleworking professionals: (1) personal costs and savings associated with telework; (2) autonomy; (3) workload and work/home-life balance; (4) working with others; and (5) professionalism and personal image. These five broad areas emerged as a way to make sense of the higher-level themes reflected in the literature, and to assist in item identification for Confirmatory Factor Analysis (CFA) with the aim of achieving as complete a set of measurement variables as possible. These themes are discussed in further detail below.

\subsection{Individual Outcomes for Teleworking Professionals}

An extensive review of the extant literature was undertaken to broadly identify individual outcomes relating to professional teleworkers. The outcomes from the review were categorized into the five areas detailed above, and broken down into 24 distinct items. 


\subsubsection{Personal costs and savings associated with telework}

Travel substitution was one of the earliest benefits associated with telework programs (Apgar, 1998), predicting reductions in travel costs (Nilles et al., 1976). However, more recent studies suggest that telework has a wider impact that may eliminate any direct benefit from travel reduction, and may in fact increase road traffic or create other travel related costs (Mokhtarian, 1997; Pinsonneault and Boisvert, 2001; Riswadkar and Riswadkar, 2009; Seaman, 1997).

Bailey and Kurland (2002) found telework programs can help organizations to reduce realestate and other operating overhead costs. However, there can be significant costs for organizations implementing telework programs, and teleworkers themselves may bear some of these costs in providing home-based work areas and work infrastructure (Bailey and Kurland, 2002; Crede, 1995; Seaman, 1997; Nilles, 1996). It would seem the literature is equivocal in terms of telework costs and savings of the three outcomes presented in Table 1.

\begin{tabular}{|l|l|}
\hline Individual outcomes & Literature Source \\
\hline Travel between home and the office & $\begin{array}{l}\text { Apgar 1998; Nilles et al. 1976; Pinsonneault } \\
\text { and Boisvert 2001; Salomon 1985; Seaman } \\
1997\end{array}$ \\
\hline Work related travel & $\begin{array}{l}\text { Apgar 1998; Mokhtarian, 1997; Riswadkar } \\
\text { and Riswadkar, 2009; Salomon 1985; Seaman } \\
1997\end{array}$ \\
\hline Costs relating to telework activities & $\begin{array}{l}\text { Bailey and Kurland 2002; Crede 1995; } \\
\text { Seaman 1997; Nilles 1996 }\end{array}$ \\
\hline
\end{tabular}

Table 1. Costs and savings for teleworkers

\subsubsection{Work autonomy}

Metzger and Von Glinow (1988) detailed the importance of having governance and management mechanisms in place for the effective management of telework. Further, a study by Guimaraes and Dallow (1999) found that the characteristics of supervisors, employees, tasks, and work environment were all significant factors for successful telework programs. Consequently, some researchers suggested having a different set of work rules for teleworkers (Feldman and Gainey, 1997; Wright and Oldford, 1993), and this is consistent with Watad and Will (2003) who found that telework can change corporate culture.

Flexibility in scheduling work and fewer interruptions are frequently cited in the literature as significant benefits for professional teleworkers (Baruch and Nicholson, 1997; Chevron and Primeau, 1996; Hunton, 2005; Pinsonneault and Boisvert, 2001). Empirical studies of telework have shown that there are perceived increases in efficiency (Apgar, 1998) and effectiveness (Bélanger, 1999), suggesting that fewer interruptions and greater work flexibility enable teleworkers to have an increased capacity to work (Apgar, 1998; DuBrin, 1991) and undertake more complex work tasks (Bélanger, 1999; Duxbury et al., 1998). Task and technology fit considerations are also important for telework practice (Bell and Kozlowski, 2002; Campbell, 1998; Campbell, 2006). Table 2 details eight distinct outcomes for teleworking professionals that relate to work autonomy. 


\begin{tabular}{|l|l|}
\hline Individual outcomes & Literature Source \\
\hline $\begin{array}{l}\text { The level of managerial control by others over } \\
\text { work }\end{array}$ & $\begin{array}{l}\text { Feldman and Gainey 1997; Guimaraes and } \\
\text { Dallow 1999; Metzger and Von Glinow 1988; } \\
\text { Wright and Oldford 1993; Watad and Will } \\
2003\end{array}$ \\
\hline Flexibility in scheduling work & $\begin{array}{l}\text { Baruch and Nicholson 1997; Chevron and } \\
\text { Primeau 1996; Pinsonneault and Boisvert } \\
2001\end{array}$ \\
\hline The complexity of work tasks & $\begin{array}{l}\text { Bélanger 1999; Duxbury et al. 1998; } \\
\text { Guimaraes and Dallow 1999 }\end{array}$ \\
\hline Capability to get things done in your job & Bélanger 1999 \\
\hline The timeit takes to get things done & Apgar 1998; Bélanger 1999 \\
\hline $\begin{array}{l}\text { The number of interruptions experienced } \\
\text { when working }\end{array}$ & $\begin{array}{l}\text { Hunton 2005; Pinsonneault and Boisvert } \\
2001\end{array}$ \\
\hline $\begin{array}{l}\text { The number of different work tasks able to be } \\
\text { undertaken }\end{array}$ & $\begin{array}{l}\text { Bell and Kozlowski 2002; Campbell 1998; } \\
\text { Campbell 2006 }\end{array}$ \\
\hline Capacity to work & Apgar 1998; DuBrin 1991 \\
\hline
\end{tabular}

Table 2. Work autonomy

\subsubsection{Workload and work/home-life balance}

A study by Duxbury et al. (1992) found that after-hours teleworkers work significantly longer hours. They also found significant role overload and work spillover interference with family life. Ahuja et al. (2007) also found that work-family conflict was a key source of stress for remote workers. In contrast, other studies cite greater work-family balanceas the major benefit for teleworkers (Dixon and Webster, 1998; Mokhtarian et al., 1998; Shamir and Salomon, 1985). The findings from investigations of the impact of telework on workload and work related pressures are also mixed. While telework can be seen as a way of alleviating a high workload and work related stress for some teleworkers (Baruch, 2001; Kanellopoulos, 2011), it may also increase organizational stress and workload for all employees (Bailey and Kurland, 2002). Table 3 presents the three outcomes identified from the literature relating to workload and work/ home-life balance.

\begin{tabular}{|l|l|}
\hline Individual outcomes & Literature Source \\
\hline Time for family and friends & $\begin{array}{l}\text { Ahuja et al. 2007; Dixon and Webster 1998; } \\
\text { Duxbury et al. 1992; Mokhtarian et al. 1998; } \\
\text { Shamir and Salomon 1985. }\end{array}$ \\
\hline Work related stress & $\begin{array}{l}\text { Ahuja et al. 2007; Baruch 2001; Bailey and } \\
\text { Kurland 2002; Kanellopoulos, 2011 }\end{array}$ \\
\hline Workload & Ahuja et al. 2007; Baruch 2001 \\
\hline
\end{tabular}

Table 3. Workload and work/ home-life balance

\subsubsection{Working with others}

Professional and social isolation are cited as negatives for intense telework environments (Apgar, 1998; Baruch and Nicholson, 1997; Chevron and Primeau, 1996). Telework can also affect personal relationships with colleagues (Apgar, 1998; Baruch, 2001). In some cases nonteleworkers must handle situations created by the absence of teleworkers from the usual place of work (Duxbury and Neufeld, 1999). Kompast and Wagner (1998) also reported that 
teleworkers can add to the workload of colleagues by sending requests from remote locations whilst remaining largely unavailable themselves. Consequently the structure of intraorganizational communication associated with remote work can play an important role in the working relationship between teleworkers, non-teleworkers and managers (Golden, 2007; Harrington and Ruppel, 1999; Watson-Manheim et al., 2012). We identified four outcomes from the literature that relate to collaborative activities and working with others. These outcomes along with their literature sources are presented in Table 4.

\begin{tabular}{|l|l|}
\hline Individual outcomes & Literature Source \\
\hline Ability to collaborate with others & $\begin{array}{l}\text { Apgar 1998; Duxbury and Neufeld 1999; } \\
\text { Harrington and Ruppel 1999; Kompast and } \\
\text { Wagner 1998 }\end{array}$ \\
\hline Relationship with work colleagues & $\begin{array}{l}\text { Apgar 1998; Baruch 2001; Golden 2007; } \\
\text { Watson-Manheim et al. 2012 }\end{array}$ \\
\hline Collegiality in the workplace & $\begin{array}{l}\text { Chevron and Primeau 1996; Kompast and } \\
\text { Wagner 1998; }\end{array}$ \\
\hline $\begin{array}{l}\text { The ability to be contacted by work colleagues } \\
\text { and/ or clients }\end{array}$ & Baruch 2001; Kompast and Wagner 1998; \\
\hline
\end{tabular}

\section{Table 4 Working with Others}

\subsubsection{Professional and personal image}

As discussed earlier, professional isolation can be a major disadvantage for teleworkers and is a particularly important factor for teleworkers working in professional roles. Professional isolation can lead to teleworkers feeling cut off from others and out of the loop in office interactions (Golden et al., 2008). This can lead to teleworkers engaging in image management activities to convince co-workers, clients and others that real work is being performed (Bailey and Kurland, 2002; Haddon, 1998; J ohnson, 1998). Teleworkers can also have concerns that work performed remotely is not professional (Bélanger and Allport, 2008; Baruch and Nicholson, 1997; Pinsonneault and Boisvert, 2001) and not of sufficient quality (Bélanger and Allport, 2008; Pinsonneault and Boisvert, 2001). Perceptions of social and professional isolation associated with telework can also impact feelings of personal achievement (Ahuja et al., 2007; Pinsonneault and Boisvert, 2001). In a similar way, isolation can diminish the organizational status of a teleworker by reducing their visibility in the workplace (Bailey and Kurland, 2002; Baruch, 2001). Paradoxically, other research has reported that there is a positive relationship between job autonomy and organizational commitment for remote workers (Apgar, 1998; Hill et al., 1998). This relationship has been shown to be moderated by perceptions of work-family conflict (Ahuja et al., 2007). Nevertheless, a reduced sense of belonging and greater professional isolation has been shown to reduce organizational commitment (Golden et al., 2008). The six potential outcomes relating to professionalism and personal image are described in Table 5 along with literature sources. 


\begin{tabular}{|l|l|}
\hline Individual outcomes & Literature Source \\
\hline The regard that others have for work produced & $\begin{array}{l}\text { Bailey and Kurland 2002; Haddon 1998; } \\
\text { Johnson 1998 }\end{array}$ \\
\hline Level of professionalism & $\begin{array}{l}\text { Bélanger and Allport 2008; Baruch and } \\
\text { Nicholson 1997; Pinsonneault and Boisvert } \\
2001 ;\end{array}$ \\
\hline The overall quality of work & $\begin{array}{l}\text { Bélanger and Allport 2008; Pinsonneault and } \\
\text { Boisvert 2001; }\end{array}$ \\
\hline Feelings of personal achievement & $\begin{array}{l}\text { Ahuja et al. 2007; Pinsonneault and Boisvert } \\
2001\end{array}$ \\
\hline Status within the organization & Bailey and Kurland 2002; Baruch 2001 \\
\hline Commitment to the organization & $\begin{array}{l}\text { Ahuja et al. 2007; Apgar 1998; Golden et al. } \\
\text { 2008; Hill et al. 1998 }\end{array}$ \\
\hline
\end{tabular}

Table 5. Professional and personal image

\subsection{Survey Development}

A survey instrument was developed incorporating the 24 items identified above and detailed in Tables 1-5 (see Appendix for instrument items). As part of the development process, the face validity of the survey items was established through a focus group consisting of three practitioners and two academic researchers who were all involved with telework and familiar with the process of survey design.

A randomized anonymous survey of CPA Australia members was conducted by telephone during December 2007. Telework is particularly important to accounting professionals because of the nature of accounting work and the need to work effectively from remote locations. Also, accounting professionals often undertake telework tasks, monitor the performance of others involved in telework, or are responsible for the allocation of resources for telework activities. Because these work practices have been undertaken over many years, relationships, factors involved, outcomes, and interactions are expected to have stabilized and therefore are more likely to be valid over the long-term, not only making this a suitable environment to study, but also one that is likely to enhance the external validity of this research.

For the purposes of the survey, telework was defined as the use of information and communication technology to support work activities away from the office. Participants were asked to indicate the impact of telework on each of the survey items using a five-point scale ranging from "a lot more" (1) to "a lot less" (5). Of the 1718 individuals contacted, 600 valid responses were obtained representing an overall response rate of 34.9 percent of the 600 accounting professional respondents, 250 reported that they undertook some level of telework representing almost 42 percent of the total sample. The 250 participants who identified as undertaking telework activity were then asked to respond to the additional 24 survey items seeking to measure the impact of telework on individual outcomes.

\section{Results}

An initial analysis was conducted to examine the potential for demographic differences both between and within the teleworker and non-teleworker groups (see Table 6). Approximately sixty-four percent of teleworkers were male $(p<001)$. There was no significant difference between the numbers of teleworkers and the number of non-teleworkers in the age group bands, with the exception of the 21 - 30 years of age where non-teleworkers were significantly higher than teleworkers $(\mathrm{p}<.004)$. Non-teleworkers were more likely to have a partner $(\mathrm{p}<.012)$, and there was no significant difference in dependent children living at home between 
teleworkers and non-teleworkers. Teleworkers had been with their current organization for 6.5 years on average and spent almost 11 hours per week working away from their main place of employment (6.5 hours during office hours and 4.3 hours outside of normal office hours). In contrast, non-teleworkers had been with their organizations for 5.4 years on average, but this difference was not significant at $\mathrm{p}<05$. Teleworkers reported working longer hours than nonteleworkers ( 3 hours extra per week on average) and this was significant $(p<.001)$.

\begin{tabular}{|l|l|l|c|}
\cline { 2 - 4 } \multicolumn{1}{l|}{} & Teleworkers & Non-Teleworkers & p-value \\
\hline Cases (n=600) & $\begin{array}{l}250 \\
(41.7 \% \text { of sample) }\end{array}$ & $\begin{array}{l}350 \\
(58.3 \% \text { of sample) }\end{array}$ & \\
\hline Gender & $36 \%$ female & $51 \%$ female & .001 \\
\hline Age & $21-30$ years $(34.8 \%)$ & $21-30$ years $(47.4 \%)$ & .004 \\
\hline Full time position & $95.2 \%$ & $96 \%$ & .635 \\
\hline Partner & $73.2 \%$ & $63.4 \%$ & .012 \\
\hline Dependents living at home & $32.8 \%$ & $27.1 \%$ & .134 \\
\hline $\begin{array}{l}\text { Tenure with current } \\
\text { organization }\end{array}$ & 6.5 years & 5.4 years & .063 \\
\hline Hours worked per week & $\begin{array}{l}45.2 \text { hours } \\
\text { (range: } 15-80 \text { hours) }\end{array}$ & $\begin{array}{l}42.2 \text { hours } \\
\text { (range: } 10-80 \text { hours) }\end{array}$ & .001 \\
\hline $\begin{array}{l}\text { Total hours of telework per } \\
\text { week }\end{array}$ & $\begin{array}{l}10.8 \text { hours per week } \\
(6.5 \text { hours during } \\
\text { office hours and } 4.3 \\
\text { hours outside office } \\
\text { hours) }\end{array}$ & Not Applicable & \multicolumn{1}{|c}{} \\
\hline
\end{tabular}

\# Chi square results testing for differences between teleworkers and non-teleworkers

Table 6. Respondent profiles

Figures $1 \mathrm{a}$ and $1 \mathrm{~b}$ show summary response data for each of the 24 items reported by the 250 teleworkers. In Figure 1a, user responses were separated into five response categories: a lot more; a bit more; no difference; a bit less; a lot less. At one extreme the responses for nine items $(5,7,10,11,13,14$ 18, 20, and 21) showed that respondents associated substantial changes with telework. While change was less pronounced for the remaining fifteen items, clear patterns still emerged. For example, there were strong increases reported in terms of getting things done (11), capacity to work (7), flexibility in scheduling work (5), collaboration (10), ability to be contacted (20), and number of different work tasks undertaken (18). Somewhat surprisingly there was a perception that telework had littleimpact on travel between home and the office (1), managerial control by others (4), and collegiality in the workplace (16). 
1. Your travel between home and the office 2. Your work related travel

3. Costs relating to your telework activities 4. The level of managerial control by others over your work 5. Flexibility in scheduling work 6. The complexity of your work tasks 7. Your capacity to work 8. The regard that others have for your work 9. Your professionalism

10. Your ability to collaborate with others 11. Your capability to get things done in your job 12. The overall quality of your work

13. The time it takes to get things don 14. The number of interruptions you experience when working 15. Your relationship with your work colleagues 16. Collegiality in the workplace

17. Your feelings of personal achievement 18. The number of different work tasks you can undertake

19. Your Commitment to the organization 20. The ability to be contacted by work colleagues and/or clients 21. Work related stress 22. Your workload 23. Status within your organization 24. Time for family and friends

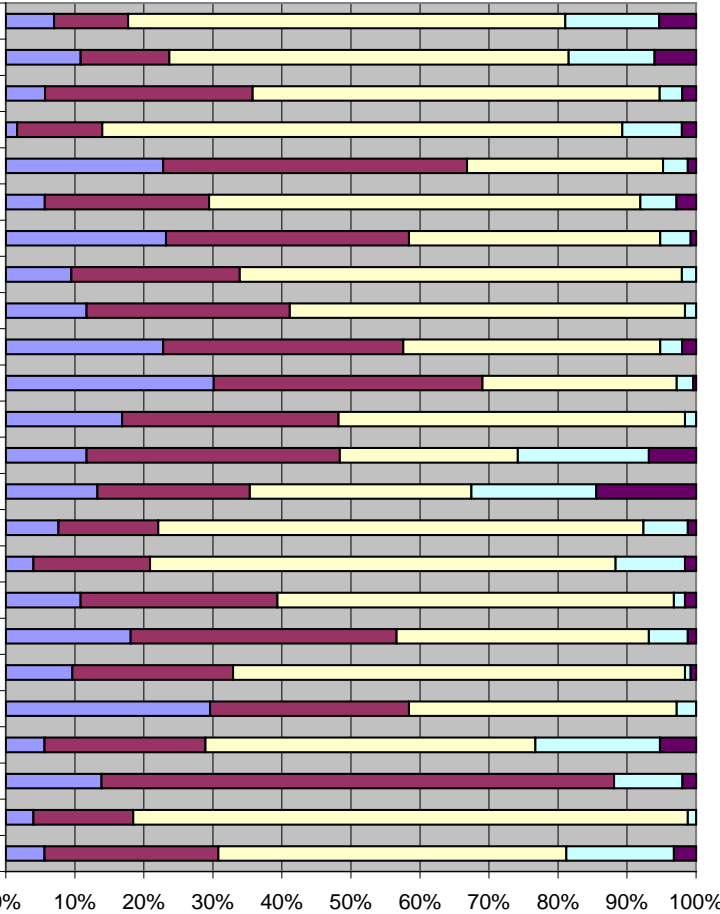

Figure 1a. Perceptions of change in work practices due to telework
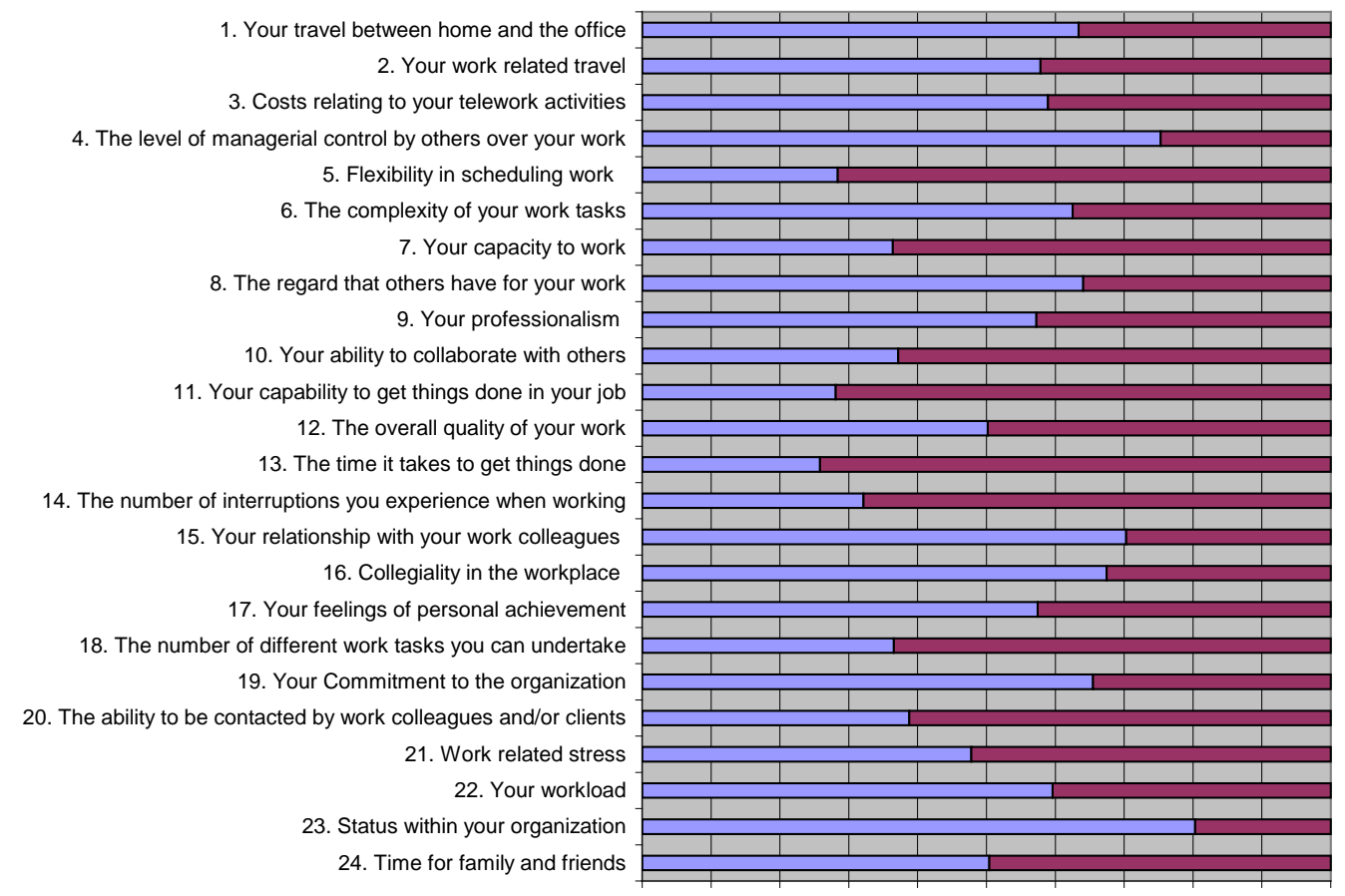

Figure 1b. Perceptions of change versus no change in work practices due to telework

It could be argued that any change from normal working practices could be disadvantageous. Consequently responses were recoded to enable comparison between the proportion of respondents reporting no change, and the proportion of respondents reporting either an increase or decrease from normal work practices. This data is presented in Figure $1 \mathrm{~b}$. While no particular pattern is evident, it is clear that a diversity of opinion existed in how telework impacted professional work practices. 
To test whether the hypothesized five-factor model provided a good fit to the data, confirmatory factor analysis was used to estimate the model and assess its fit to the 250 teleworker data cases. For the dataset of teleworkers $(\mathrm{N}=250)$, Bartlett's test of sphericity is significant $(p<0.000)$, thus the hypothesis that the intercorrelation matrix involving the 24 survey items is an identity matrix is rejected. Thus from the perspective of Bartlett's test, factor analysis is feasible. As Bartlett's test is almost always significant, a more discriminating index of factor analyzability is the Kaiser-Meyer-Olkin (KMO) indicator. For this data set, it is 0.757 which is large, so the KMO also supports factor analysis.

The five factors identified from the literature included (1) Personal costs and savings associated with telework; (2) Work autonomy; (3) Workload and work/ home-life balance; (4) Working with others; and (5) Professional and personal image. However, the model showed very poor fit $\left(\chi^{2}=1008.4 ; D F=252\right)$. Attempts to improve the model using the modification index and Akaike's information criteria (Kaplan, 1991) reduced the Chi-square value only marginally ( $\chi^{2}$ $=921 ; \mathrm{DF}=252$ ). Thus, the initial model was deemed an unsuitable representation of the data and its underlying constructs.

Follow up exploratory factor analysis (EFA) was then used to examine whether the 24 items could be factored to a smaller number of constructs that provide a more meaningful basis for understanding how telework outcomes are structured (Sass and Schmitt, 2010; Schmitt, 2011). Factors were extracted using Principal Axis Factoring with Promax oblique rotation method and Kaiser Normalization. Oblique rotation is preferred when factors are correlated (Tabachnick and Fidell, 2007) as was expected and later confirmed in subsequent analysis (see Table 8), and Promax rotation is relatively efficient at achieving simple oblique structure (Abdi, 2003). Initially seven factors returned eigenvalues greater than one (i.e., the K1rule of thumb). However, on closer inspection, the seventh factor returned an eigenvalue only marginally above 1 and had only 2 items with loadings greater than 0.3 (item 13 with 0.365 , and item 14 with 0.368). After considering these issues and reviewing the scree plot (see Figure 2), it was concluded that a six-factor solution should be retained for further analysis. While the K1 rule has been shown to overstate the number of factors in previous studies, the scree test is frequently cited as one of the best methods available for deciding how many factors to retain for EFA (Costello and Osborne, 2005; Horn, 1965). The resulting factor structure is provided in Table 7.

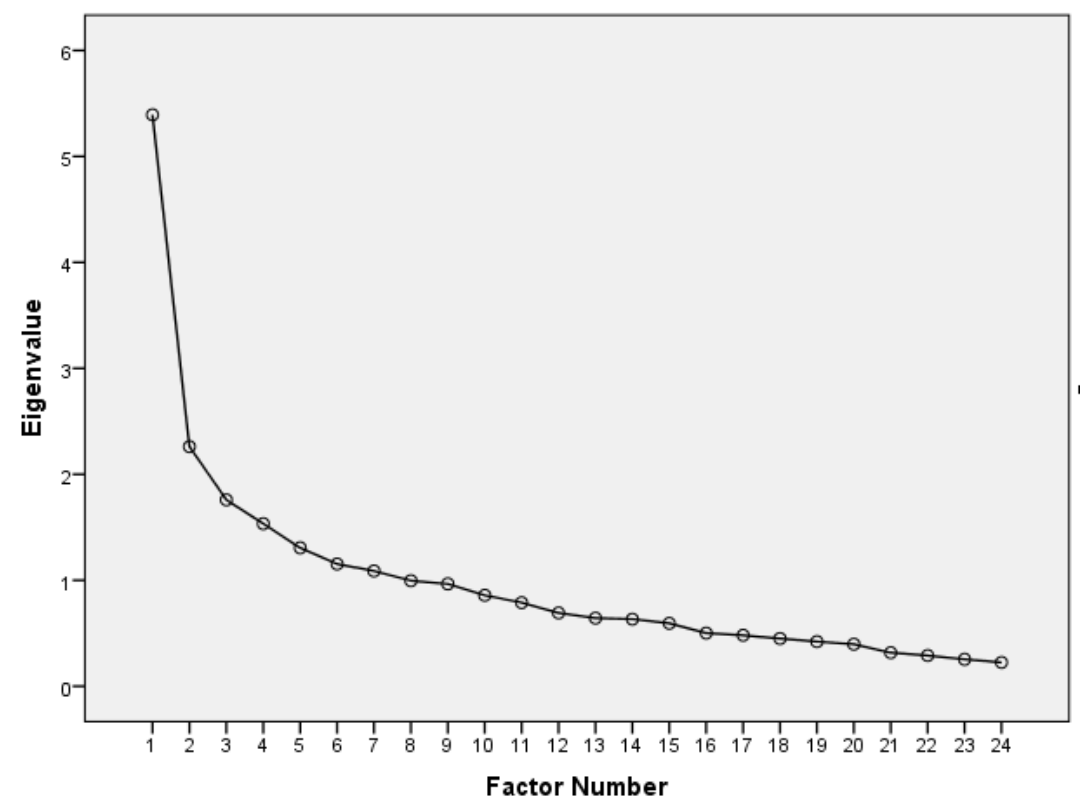

Figure 2. Scree Plot

Factor 1 was interpreted as reflecting Effectiveness as it contained items relating to the effective performance of work including ability to collaborate, get things done, being contactable, 
quality of work and scheduling. Factor 2 was interpreted as Self-assurance as this factor contained three items concerned with organizational commitment, personal achievement, and status. Factor 3 was interpreted as Working with Others as it contained items concerned with interpersonal relationships and collegiality in the workplace. Factor 4 was interpreted as Work Pressure as it grouped variables reflecting work-related stress, workload, and time available for personal relationships. Factor 5 was seen to reflect items related to an individual's Personal Image including professionalism and the regard others have for one's work. Factor 6 was more difficult to interpret because of the multiplicity of items that loaded. However, this factor was labelled Physicality as the items with higher loadings reflected aspects of location and travel between locations.

More than 55 percent of total variance was explained by the six factors. Only three variables (items 9, 12 and 18) were found to load on more than one factor (i.e., loading scores $\geq 0.5$ ) suggesting that each factor reflected a different aspect of the consequences of telework. As very little item complexity was evident, the rotated factor solution was deemed to approximate simple structure and therefore suitable for analysis of the underlying factor structure.

Factor reliability was assessed using Cronbach's alpha with each factor examined to assess if the removal of items improved reliability. The examination showed that factor reliability could be improved for Factor 3 (Working with Others) and Factor 4 (Work pressure). Factor 3 initially returned a Cronbach's alpha coefficient of .55. However this increased to .77 when item 14 (the number of interruptions you experience when working) was excluded. Factor 4 returned a Cronbach's alpha coefficient of .63 which increased to .68 when item 24 (Time for family and friends) was excluded. Items were also removed from Factor 6 (Physicality). However Cronbach's alpha could not be substantially improved. Three items were removed from this scale to improve internal consistency between the remaining items because of low factor loadings. The three items removed were: costs relating to your telework activities (item 3); the complexity of your work tasks (item 6); and the time it takes to get things done (item 13). Although removed from further consideration, Items 3, 6, 13, 14 and 24 are reported in subsequent tables for completeness.

Table 8 reports correlations for demographic variables and scores for each of the six factors. The analysis shows that there are strong correlations between demographic variables suggesting strong links between such attributes as age, tenure, hours worked, number of dependents and full-time status. Most interesting was that the amount of telework hours per week was not significantly correlated with any personal attributes, but was significantly correlated $(\mathrm{P}<05)$ level with number of hours worked. This result suggests that telework may facilitatelonger work hours which has implications for outcomes such as work-life balance (see Maruyama et al., 2009). 


\begin{tabular}{|c|c|c|c|c|c|c|c|}
\hline Individual Consequences & $\begin{array}{c}\text { Item } \\
\text { No. }\end{array}$ & $\begin{array}{c}\text { Factor 1: } \\
\text { Effectiveness }\end{array}$ & $\begin{array}{c}\text { Factor 2: } \\
\text { Self-assurance }\end{array}$ & $\begin{array}{c}\text { Factor 3: } \\
\text { Working } \\
\text { with Others }\end{array}$ & $\begin{array}{l}\text { Factor 4: } \\
\text { Work } \\
\text { Pressure } \\
\end{array}$ & $\begin{array}{c}\text { Factor 5: } \\
\text { Professional } \\
\text { Image }\end{array}$ & $\begin{array}{c}\text { Factor 6: } \\
\text { Physicality }\end{array}$ \\
\hline Your capability to get things done in your job & 11 & .780 & .409 & .308 & .230 & .371 & .093 \\
\hline Your ability to collaborate with others & 10 & .668 & .383 & .479 & .334 & .316 & .297 \\
\hline The ability to be contacted by work colleagues and/ or clients & 20 & .640 & .381 & .423 & .384 & .203 & .190 \\
\hline The number of different work tasks you can undertake & 18 & .628 & .583 & .353 & .329 & .217 & .278 \\
\hline Your capacity to work & 7 & .627 & .153 & .132 & .156 & .312 & .103 \\
\hline The overall quality of your work & 12 & .613 & .508 & .295 & .110 & .530 & .087 \\
\hline Flexibility in scheduling work & 5 & .364 & .173 & -.056 & -.031 & .109 & .067 \\
\hline Your commitment to the organization & 19 & .375 & .759 & .384 & .126 & .383 & .058 \\
\hline Your feelings of personal achievement & 17 & .295 & .737 & .250 & .078 & .337 & .098 \\
\hline Status within your organization & 23 & .397 & .541 & .394 & .227 & .341 & .178 \\
\hline Your relationship with your work colleagues & 15 & .303 & .438 & .885 & .216 & .395 & .064 \\
\hline Collegiality in the workplace & 16 & .202 & .330 & .660 & .038 & .235 & .055 \\
\hline The number of interruptions you experience when working & 14 & .201 & -.042 & .410 & .391 & -.113 & .302 \\
\hline Work related stress & 21 & .290 & .133 & .261 & .817 & .020 & .499 \\
\hline Your workload & 22 & .263 & .249 & .201 & .663 & .132 & .289 \\
\hline Time for family and friends & 24 & -.013 & .104 & .010 & -.387 & .121 & -.032 \\
\hline Your professionalism & 9 & .540 & .501 & .305 & .120 & .747 & .167 \\
\hline The regard that others have for your work & 8 & .352 & .359 & .307 & .118 & .737 & .107 \\
\hline Your work related travel & 2 & .181 & .049 & .048 & .295 & -.035 & .560 \\
\hline Your travel between home and the office & 1 & .070 & .041 & .003 & .150 & -.026 & .525 \\
\hline The level of managerial control by others over your work & 4 & .130 & .158 & .211 & .171 & .221 & .424 \\
\hline The time it takes to get things done & 13 & -.027 & .090 & .135 & .194 & .028 & .316 \\
\hline The complexity of your work tasks & 6 & .081 & .079 & .137 & .192 & .112 & .296 \\
\hline Costs relating to your telework activities & 3 & .044 & -.039 & -.036 & -.018 & .003 & .262 \\
\hline Eigenvalue & & 5.393 & 2.261 & 1.759 & 1.534 & 1.306 & 1.154 \\
\hline Percent of total variance explained & & $22.47 \%$ & $9.42 \%$ & $7.33 \%$ & $6.39 \%$ & $5.44 \%$ & $4.81 \%$ \\
\hline Cronbach's Alpha & & .80 & .71 & $.77^{\wedge}$ & $.68^{\wedge}$ & .75 & $.53^{\wedge}$ \\
\hline
\end{tabular}

Participants were asked to indicate the impact of telework on each item using a five-point scale ranging from "a lot more" (1) to "a lot less" (5).

Factors were extracted using Principal Axis Factoring and Promax rotation with Kaiser Normalization. Rotation converged in 7 iterations.

^Cronbach's alpha for Factor 3 (Working with Others) increased to .77 (up from .55) when item 14 was removed, and to .68 (up from .63) for Factor 4 (Work Pressure) when item 24 was removed. Cronbach's alpha for Factor 6 reduced slightly to .53 (down from .55) when items, 3, 6 and 13 were removed to improve internal consistency.

Table 7. Factor analysis of user perceptions of the impact of telework 


\begin{tabular}{|c|c|c|c|c|c|c|c|c|c|c|c|c|c|c|c|c|}
\hline & Mean & SD & $\mathbf{1}$ & 2 & 3 & 4 & 5 & 6 & 7 & 8 & 9 & 10 & 11 & 12 & 13 & 14 \\
\hline $\begin{array}{l}\text { 1. Gender (Male=1; } \\
\text { Female=2) }\end{array}$ & 1.36 & .48 & 1 & & & & & & & & & & & & & \\
\hline $\begin{array}{l}\text { 2. Age (mean category = } \\
21-30 \text { years) }\end{array}$ & 3.33 & 1.27 & $-.435^{* *}$ & 1 & & & & & & & & & & & & \\
\hline $\begin{array}{l}\text { 3. Full Time Status } \\
(\mathbf{F T}=1 ; \mathbf{P T}=2)\end{array}$ & 1.05 & .21 & -.050 & $.281^{* *}$ & 1 & & & & & & & & & & & \\
\hline 4. Partner $(\mathrm{Yes}=1 ; \mathrm{No}=2)$ & 1.27 & .44 & .116 & $-.263^{* *}$ & -.051 & 1 & & & & & & & & & & \\
\hline $\begin{array}{l}\text { 5. Dependents (Yes=1; } \\
\text { No=2) }\end{array}$ & 1.67 & .47 & $.217^{* *}$ & $-.256^{* *}$ & .037 & $.250 * *$ & 1 & & & & & & & & & \\
\hline 6. Tenure (Years) & 6.45 & 7.88 & $-.276^{* *}$ & $.474^{* *}$ & .068 & $-.153^{*}$ & $-.142 *$ & 1 & & & & & & & & \\
\hline $\begin{array}{l}\text { 7. Hours Worked Per } \\
\text { Week }\end{array}$ & 45.19 & 8.96 & $-.223^{* *}$ & $.173^{* *}$ & $-.536^{* *}$ & -.053 & $-.162 *$ & $.174^{* *}$ & 1 & & & & & & & \\
\hline $\begin{array}{l}\text { 8. Hours of Telework Per } \\
\text { Week }\end{array}$ & 10.85 & 12.98 & -.083 & .125 & .077 & -.092 & -.049 & .007 & $.155^{*}$ & 1 & & & & & & \\
\hline 9. Effectiveness ( 7 items) & 15.55 & 4.11 & .044 & $-.143^{*}$ & -.035 & -.063 & -.027 & -.066 & -.013 & $-.181 * *$ & 1 & & & & & \\
\hline $\begin{array}{l}\text { 10. Self-assurance (3 } \\
\text { items) }\end{array}$ & 7.94 & 1.61 & -.079 & -.053 & $-.133 *$ & -.065 & -.041 & -.026 & $.192^{* *}$ & .063 & $.469^{* *}$ & 1 & & & & \\
\hline $\begin{array}{l}\text { 11. Working With Others } \\
\text { (3 items) }\end{array}$ & 8.65 & 1.99 & -.100 & .041 & .031 & -.005 & -.103 & 159* & .095 & -.015 & $.304^{* *}$ & $.241^{* *}$ & 1 & & & \\
\hline $\begin{array}{l}\text { 12. Work Pressure ( } 3 \\
\text { items) }\end{array}$ & 8.73 & 1.88 & -.052 & .059 & $-.137 *$ & -.003 & -.120 & .003 & .049 & -.063 & $.213^{* *}$ & .104 & $.192^{* *}$ & 1 & & \\
\hline $\begin{array}{l}\text { 13. Professional Image (2 } \\
\text { items) }\end{array}$ & 5.07 & 1.27 & .041 & $-.128 *$ & -.091 & .005 & -.044 & -.024 & .009 & -.110 & $.502^{* *}$ & $.421^{* *}$ & $.207^{* *}$ & .073 & 1 & \\
\hline 14. Physicality (6 items) & 17.00 & 2.82 & -.036 & -.034 & -.007 & -.014 & -.094 & .067 & -.045 & -.103 & $.136^{*}$ & .084 & $.156^{*}$ & $.246^{* *}$ & .123 & 1 \\
\hline
\end{tabular}

** Correlation is significant at the 0.01 level (2-tailed).

* Correlation is significant at the 0.05 level (2-tailed).

Table 8. Correlations between demographic variables and factor scores 
The correlations for the six factors revealed interesting patterns. As might be expected, scores for all six factors were on the most part strongly associated with one another. However, only the Effectiveness factor was significantly correlated with hours of telework per week $(p<01)$ and this association was a negative one. The strongest correlations $(>.4)$ were recorded between the three factors Self-assurance, Effectiveness and Professional Image.

\subsection{Scale Construction}

With factors relating to individual consequences of telework identified along with items that related to each of those factors, we were in a position to extend our work to develop an initial scale for the measurement of an individual's consequences of telework. Our procedures are consistent with (DeVellis, 2003) and the practice of using items from theliterature. We further analysed the items relating to the six factors with a view to develop a more parsimonious model than would be suggested by the factor analysis. A review of the factor loadings indicated that all factors loaded primarily onto one factor (convergent validity), and the constructs AVE values are larger than correlations with other constructs.

We used IBM SPSS AMOS Version 22 to test our measurement model. Convergent and discriminate validity for each of the six factors was evaluated resulting in no significant loadings on other factors, and a Chi-square value significantly smaller than the independent model. The Chi-square/ df value of 3.2 is acceptable and an RMSEA of 0.094 represents a mediocre fit (Hu and Bentler, 1999). A GFI of 0.774 does not represent a strong fit, indicating further work is needed to better refine the scale.

\section{Discussion}

We initially categorized individual consequences of telework based on five broad areas identified in the extant literature. Although confirmatory factor analysis did not support our hypothesized structure, follow-up exploratory factor analysis revealed six latent factors highlighting the complexity of individual consequences for teleworking. Although caution is required in interpreting our results, the findings signal that two of the three proximal outcomes identified by Gajendran and Harrison (2007) are perhaps multi-dimensional and, as argued earlier, other important elements have been overlooked. Gajendran and Harrison's (2007) proximal outcomes Personal autonomy and Relationship Quality did not emerge as latent constructs for teleworking professionals in this study. However, items reflecting these issues were embedded in the Effectiveness, Collegiality, and Physicality factors.

Table 9 maps the five factors outlined in the literature against the six factors that emerged from exploratory factor analysis. The Workload and Work-home Life Balance construct proposed from the literature was fully accounted for by the Work Pressures factor. Items identified in the literature describing Professionalism and Personal Image were largely included in either the Professional Image or Self-assurance factors. Similarly items identified in the literature concerned with Work Autonomy were largely contained in the Effectiveness and Physicality factors. Work Autonomy, which was prominent in the literature, proved to be a particularly complex construct thereby highlighting the need to more fully explore the nature and consequences of telework for professional knowledge workers.

The Costs and Savings construct gleaned from the literature was accounted for by Physicality which emphasised travel and time overheads. However, Costs didn't seem to matter very much to individuals (but they certainly do to organisations). Work related stress is an important factor, and while it has a relatively high loading onto Physicality (0.499), it loads much higher on Work Pressure (0.817). It is important to Physicality, but not as important as Work Related Travel (0.560) and Travel between Home and the Office (0.525). Working with Others was subsumed by the Collegiality and Effectiveness factors which suggested that teamwork in a telework environment may be dependent on individual traits relating to the individual's personality and their desire to be open to contact from others to collaborate. 
The findings from our analysis suggest that professional workers have perspectives on telework that incorporate aspects from all three models, Campbell and McDonald (2009), Gajendran and Harrison (2007), and Hunton and Harmon (2004). The next step in our work is to develop a more formalised and testable model that will better inform telework from the individual's perspective and determine the drivers for a successful telework arrangement.

\section{Summary and Conclusion}

This study examined the underlying structure of individual outcomes for teleworking professionals. The research was motivated by the need to build on earlier work by Campbell and McDonald (2009), Gajendran and Harrison (2007), and Hunton and Harmon (2004) to develop a better understanding of individual outcomes and their association with telework practices, particularly in a professional worker context. From the literature, we identified 24 consequences affecting teleworkers with the aim of asking professional knowledge workers how each item impacted on them as teleworking individuals (not from an organisation perspective, as most previous studies have done). To achieve this we surveyed 600 accounting professionals, of whom 250 undertook telework. The resultant exploratory factor analysis of these 250 cases revealed six significant constructs that defined individual outcomes for teleworking professionals. These outcomes are not only associated with effectiveness and work pressure, but also with perceptions of professionalism, collegiality, physicality and professional image. 


\begin{tabular}{|c|c|c|c|c|c|c|c|}
\hline Factor & Item No. & Telework Activities & $\begin{array}{c}\text { Costs and } \\
\text { Savings }\end{array}$ & $\begin{array}{c}\text { Work } \\
\text { Autonomy }\end{array}$ & $\begin{array}{c}\text { Workload } \\
\text { and work- } \\
\text { home life } \\
\text { balance }\end{array}$ & $\begin{array}{l}\text { Working } \\
\text { with } \\
\text { others }\end{array}$ & $\begin{array}{c}\text { Professional } \\
\text { and } \\
\text { personal } \\
\text { Image }\end{array}$ \\
\hline 1. Effectiveness & $\begin{array}{c}11 \\
10 \\
20 \\
18 \\
7 \\
12 \\
5\end{array}$ & $\begin{array}{l}\text { Your capability to get things done in yourjob } \\
\text { Your ability to collaborate with others } \\
\text { The ability to be contacted by work colleagues and/ or clients } \\
\text { The number of different work tasks you can undertake } \\
\text { Your capacity to work } \\
\text { The overall quality of your work } \\
\text { Flexibility in scheduling work }\end{array}$ & & $\begin{array}{l}\mathbf{x} \\
\mathbf{x} \\
\mathbf{x} \\
\mathbf{x}\end{array}$ & & $\begin{array}{l}\mathbf{x} \\
\mathbf{x}\end{array}$ & $\mathbf{x}$ \\
\hline 2. Self-assurance & $\begin{array}{l}19 \\
17 \\
23\end{array}$ & $\begin{array}{l}\text { Your commitment to the organization } \\
\text { Your feelings of personal achievement } \\
\text { Status within your organization }\end{array}$ & & & & & $\begin{array}{l}\mathbf{x} \\
\mathbf{x} \\
\mathbf{x}\end{array}$ \\
\hline 3. Working with Others & $\begin{array}{l}15 \\
16 \\
14\end{array}$ & $\begin{array}{l}\text { Your relationship with your work colleagues } \\
\text { Collegiality in the workplace } \\
\text { The number of interruptions you experience when working }\end{array}$ & & $\mathbf{x}$ & & $\begin{array}{l}\mathbf{x} \\
\mathbf{x}\end{array}$ & \\
\hline 4. Work pressure & $\begin{array}{l}21 \\
22 \\
24\end{array}$ & $\begin{array}{l}\text { Work related stress } \\
\text { Your workload } \\
\text { Time for family and friends }\end{array}$ & & & $\begin{array}{l}\mathbf{x} \\
\mathbf{x} \\
\mathbf{x}\end{array}$ & & \\
\hline 5. Professional Image & $\begin{array}{l}9 \\
8\end{array}$ & $\begin{array}{l}\text { Your professionalism } \\
\text { The regard that others have for your work }\end{array}$ & & & & & $\begin{array}{l}\mathbf{x} \\
\mathbf{x}\end{array}$ \\
\hline 6. Physicality & $\begin{array}{l}2 \\
1 \\
4 \\
13 \\
6 \\
3\end{array}$ & $\begin{array}{l}\text { Your work related travel } \\
\text { Your travel between home and the office } \\
\text { The level of managerial control by others over your work } \\
\text { The time it takes to get things done } \\
\text { The complexity of your work tasks } \\
\text { Costs relating to your telework activities }\end{array}$ & $\begin{array}{l}\mathbf{x} \\
\mathbf{x} \\
\mathbf{x}\end{array}$ & $\begin{array}{l}\mathbf{x} \\
\mathbf{x} \\
\mathbf{x}\end{array}$ & & & \\
\hline
\end{tabular}

Table 9. Mapping of the six factor loadings against the literature domains 
We suggest that the six factors greatly inform modelling of proximal outcomes of telework thereby enhancing opportunities for further empirical research and theoretical development. Future research should seek to better understand how each of the six factors relates to actual telework behaviour. Information and communication technologies are rapidly changing the workplace and this study has shown there is latent structure underlying outcomes for teleworkers. Future research is also required to test the relationship between these individual factors and organizational consequences, and social impact as suggested by the SBTF.

\section{Limitations}

There are three important limitations resulting from this study that also create opportunities for future research (e.g., see Padsakoff et al., 2003). Firstly, our analysis relied on a crosssectional design so our results may have been affected by differences within our sample where confounding variables such as experience were not equally distributed. Although this possibility was mitigated to some extent by focusing on accounting professionals, our understanding of individual consequences would be greatly strengthened through further research using in-depth case studies.

Secondly, reliance on self-report data may have introduced method bias to our results. Padsakoff et al. (2003) identified several potential method effects relating to biases introduced by item characteristics and individual behaviours such as affectivity, social desirability, assumptions about relationships amongst items, and acquiescence to attitudinal statements. Future research should test our findings using data obtained from different sources. For example, it may be particularly advantageous to contrast the perspective of teleworkers with other stakeholder viewpoints including those of family members, colleagues, managers, and clients.

Thirdly, and perhaps the most significant study limitation, concerns the method used to analyse the data. The exploratory factor analysis must be interpreted carefully as the results have not been confirmed against other sample data sets. Our results could be sample specific and not generalize well to the population of teleworkers. Also the measurement instrument requires additional refinement to improve construct and criterion reliability. The initial description and classification of items into different outcome domains and later interpretation of constructs was a subjective process relying on published measurement items. Further work is required to establish the validity of these items and the constructs that were subsequently identified. In particular, Factor 6 requires further development and refinement to improve internal reliability.

\section{Acknowledgment}

This research was supported under Australian Research Council's Discovery Projects funding scheme (project number DP120104521).

\section{References}

Abdi, H., 2003. Factor Rotation in Factor Analyses, in The SAGE Encyclopedia of Social Science Research Methods, M. S. Lewis-Beck, A. E. Bryman and T. F. Liao eds., California: Sage Publications, 792-795.

Ahuja, M.K., Chudoba, K.M, Kavmar, C.J., McKnight, D.H., George, J.F., 2007. IT Road Warriors: Balancing Work-Family Conflict, Job Autonomy, and Work Overload to Mitigate Turnover Intentions. MIS Quarterly 31 (1), 1-17.

Apgar, M., 1998. The Alternative Workplace: Changing Where and How People Work. Harvard Business Review 76 (3), 121-30.

Bailey, D.E., Kurland, N.B., 2002. A Review of Telework Research: Findings, New Directions, and Lessons for The Study of Modern Work. J ournal of Organizational Behaviour 23 (4), 383-400. 
Baruch, Y., Nicholson, N., 1997. Home, Sweet Work: Requirements for Effective Home Working. J ournal of General Management 23, 15- 30.

Baruch, Y. 2001. The Status of Research on Teleworking and the Agenda for Future Research. International J ournal of Management Reviews 3 (2), 113- 129.

Bélanger F., Collins, R.W., 1998. Distributed Work Arrangements: A Research Framework, Information Society 14 (2), 137-152.

Bélanger F., 1999. Workers' Propensity to Telecommute: An Empirical Study. Information \& Management 35, 139-153.

Bell, B.S., Kozlowski, S.W.J., 2002. A Typology of Virtual Teams Implications for Effective Leadership. Group \& Organization Management 27 (1), 14-49.

Campbell, J.A., 1998. Participation in Videoconferenced Meetings: User Disposition and Meeting Context. Information \& Management 34 (6), 329-338.

Campbell, J., 2006. Media Richness, Communication Apprehension and Participation in Group Videoconferencing. Journal of Information, Information Technology, and Organizations 1, 87-96.

Campbell, J . and McDonald, C., 2009. Defining a Conceptual Framework for Telework and an Agenda for Research in Accounting and Finance. International Journal of Business Information Systems 4 (4), 387-402.

Chevron, J., Primeau, M., 1996. The Telecommuting Innovation Opportunity. J ournal of Consumer Marketing 13 (4), 40-8.

Costello, A.B., Osborne, J.W., 2005. Best Practices in Exploratory Factor Analysis: Four Recommendations for Getting the Most from Your Analysis. Practical Assessment, Research \& Evaluation 10 (7), 1-9.

Crede, K.L., 1995. The Environmental Effects of The Computer Age. IEEE Transactions on Professional Communication 38 (1), 33-40.

Davenport, T., Pearlson, K., 1998. Two Cheers for the Virtual Office. Sloan Management Review 39 (4), 51-65.

Deetz, S., 2005. Critical Theory, In Engaging organizational communication theory: Multiple perspectives, S. May and D. Mumby eds., Thousand Oaks, CA: SAGE, 85-11.

DeVellis, R.F. 2003. Scale Development: Theory and Applications. Thousand Oaks, California: Sage Publications.

Dixon, T.L., Webster, J., 1998. Family Structure and the Telecommuter's Quality of Life. J ournal of End User Computing 10 (4), 42-50.

DuBrin, A.J., 1991. Comparison of the J ob Satisfaction and Productivity of Telecommuters Versus In-House Employees: A Research Note on Work in Progress. Psychological Report 68, 1223-34.

Duxbury, L.E., Higgins, C.A., Mills, S., 1992. After Hours Telecommuting and Work-Family Conflict: A Comparative Analysis. Information Systems Research 3, 173-90.

Duxbury, L.E., Neufeld, D., 1999. An empirical evaluation of the impacts of telecommuting on intra-organizational communication. Journal of Engineering \& Technology Management 16, 1-28.

Duxbury, L.E., Higgins, C.A., Neufeld, D., 1998. Telework and the Balance Between Work and Family: Is Telework Part of the Problem or Part of the Solution? In The Virtual Workplace, M. Igbaria and M. Tan eds., Hershey, PA: Idea Group Publishing, 218- 255.

Feldman, D., Gainey, T., 1997. Patterns of Telecommuting and Their Consequences: Framing the Research Agenda. Human Resource Management Review 7 (4), 369-88. 
Gajendran, R. S., Harrison, D. A., 2007. The Good, the Bad and the Unknown About Telecommuting: Meta-Analysis of Psychological Mediators and Individual Consequences. J ournal of Applied Psychology 92, 1524-1541.

Golden, T., 2007. Co-Workers Who Telework and the Impact on those in the Office: Understanding the Implications of Virtual Work for Co-Worker Satisfaction and Turnover Intentions. Human Relations 60 (11), 1641-1667.

Golden, T., Veiga, J J ., Dino, R.N., 2008. The Impact of Professional Isolation on Teleworker J ob Performance and Turnover Intentions: Does Time Spent Teleworking, Interacting Face-To-Face, or Having Access to Communication-Enhancing Technology Matter? J ournal of Applied Psychology 93 (6), 1412-1421.

Gray, P., 1997. A Demand-Side Approach to Telecommuting: The Integrated Workplace Strategies Concept. Information Systems Management 14 (4), 21-8.

Guimaraes, T., Dallow, P., 1999. Empirically Testing the Benefits, Problems and Success Factors for Telecommuting Programs. European J ournal of Information Systems 8 (1), 40-54.

Haddon L., 1998. The Experience of Teleworking: A View from the Home. In Teleworking: International Perspectives, P.J. Jackson and J.M. Van der Wielen eds., London: Routledge Press, 136- 143.

Harrington, S.J ., Ruppel, C.P., 1999. Telecommuting: A Test of Trust, Competing Values, and Relative Advantage. IEEE Transactions on Professional Communication 42 (4), 223.

Hill, E.J., Miller, B.C., Weiner, S.P., Colihan, J., 1998. Influences of the Virtual Office on Aspects of Work and Work/ Life Balance. Personnel Psychology 51(3), 667-83.

Horn, J.L., 1965. A Rationale and Test for the Number of Factors in Factor Analysis. Psychometrika 32, 179-185.

Hu, L.-t., Bentler, P.M. 1999. "Cutoff Criteria for Fit Indexes in Covariance Structure Analysis: Conventional Criteria Versus New Alternatives.," Structural Equation Modeling 6 (1), pp. 1-55.

Hunton, J.E., Harmon, W.K., 2004. A Model for Investigating Telework in Accounting. International J ournal of Accounting Information Systems 5 (4), 417-427.

Hunton, J.E., 2005. Behavioural Self-Regulation of Telework Locations: Interrupting Interruptions! J ournal of Information Systems 19 (2), 111-140.

J ohnson, S.A., 1998. Teleworking Service Management: Issues for an Integrated Framework. In Teleworking: International Perspectives. From Telecommuting to the Virtual Organization, J ackson PJ , Van der Wielen J eds. London: Routledge Press, 185- 206.

Kanellopoulos, D.N., 2011. How Can Teleworking be Pro-poor? Journal of Enterprise Information Management 24 (1), 8-29.

Kaplan, D. 1991. On the Modification and Predictive Validity of Covariance Structure Models. Quality \&Quantity 25, 307-314.

Kompast M., Wagner, I., 1998. Telework: Managing Spatial, Temporal and Cultural Boundaries. In Teleworking: International Perspectives (pp. 95- 117), J ackson PJ , van der Wielen J M eds., London: Routledge Press.

Matos, K., Galinsky, E., 2014. 2014 National Study of Employees, Families and Work Institute, http:/ / familiesandwork.org/ downloads/ 2014NationalStudyOfEmployers.pdf, [accessed 15 April 2016].

Metzger, R.O., Von Glinow, M.A., 1988. Off-Site Workers: At Home and Abroad. California Management Review 30 (3), 101-111. 
Mokhtarian, P.L., 1997. The Transportation Impacts of Telecommuting: Recent Empirical Findings. In Understanding Travel Behaviour in an Era of Change, eds. P. R. Stopher and M. Lee-Gosselin. Oxford, Great Britain: Pergamon (Elsevier Science Ltd.).

Mokhtarian, P.L., Bagley, M.N., Salomon, I, 1998. The Impact of Gender, Occupation, and Presence of Children on Telecommuting Motivations and Constraints. J ournal of the American Society for Information Science 49 (12), 1115-34.

Maruyama, T., Hopkinson, P.G., J ames, P.W., 2009. A Multivariate Analysis of Work- life Balance Outcomes from a Large-scale Telework Programme. New Technology, Work and Employment 24 (1), 76-88.

Maruyama, T., Tietze, S., 2012. From Anxiety to Assurance: Concerns and Outcomes of Telework. Personnel Review 41 (4), 450-469.

Morganson, V.J., Major, D.A., Oborn, K.L., Verive, J.M., Heelan, M.P., 2010. Comparing Telework Locations and Traditional Work Arrangements: Differences in Work-Life Balance Support, J ob Satisfaction, and Inclusion. J ournal of Managerial Psychology 25 (6), 578-595.

Nilles, J ., 1996. What Does Telework Really Do To Us? World Transport Policy and Practice 2 (1), 15-23.

Nilles, J., Carlson, Jr., F.R., Gray, P., Hanneman, G.J., The TelecommunicationsTransportation Tradeoff: Options for Tomorrow. New York, NY: J ohn Wiley and Sons, 1976.

Orlikowski, W., 2000. Using Technology and Constituting Structures: A Practice Lens for Studying Technology in Organizations. Organization Science 11 (4), 404-428.

Pinsonneault, A., Boisvert, M., 2001. The Impacts of Telecommuting on Organizations and Individuals: A Review of the Literature, in J ohnson, N.J . ed., Telecommuting and Virtual Offices: Issues and Opportunities, Hershey, PA: Idea Group Publishing, 163-85.

Rafaeli, S., Ravid, G., 2003. Information Sharing as Enabler for the Virtual Team: An Experimental Approach to Assessing the Role of Electronic Mail in Disintermediation. Information Systems J ournal 13 (2), 191- 206.

Riswadkar, A., Riswadkar, A.V., 2009. Balancing the Risks of Remote Working: Walking the Telecommuting Line. The J ohn Liner Review 23 (2), 1-5.

Reinsch, N.L., 1997. Relationship Between Telecommuting Workers and their Managers: An Exploratory Study. J ournal of Business Communication 34 (4), 343-69.

Salomon, I., 1985. Telecommunications and Travel: Substitution or Modified Mobility? J ournal of Transport Economics and Policy 19, 219- 235.

Sass, D.A., Schmitt, T.A., 2010. A Comparative Investigation of Rotation Criteria within Exploratory Factor Analysis. Multivariate Behavioral Research 45 (1), 73-103.

Schmitt, T.A., 2011. Current Methodological Considerations in Exploratory and Confirmatory Factor Analysis. J ournal of Psychoeducational Assessment 29 (4), 304-321.

Seaman, M.J ., 1997. Telecommuting: a Transportation Planner's View. Information Systems Management 14 (4), 73-5.

Shamir, B., Salomon, H., 1985. Work-at-Home and the Quality of Working Life. The Academy of Management Review 10 (3), 455-65.

Siha, S.M., Monroe, R.W., 2006. Telecommuting's Past and Future: A Literature Review and Research Agenda. Business Process Management J ournal 12 (4), 455-482.

Tabachnick, B.G., Fidell, L.S. 2007. Using multivariate statistics, 5th ed., Upper Saddle River, NJ : Pearson Allyn \& Bacon. 
Watad, M.M., DiSanzo, F.J ., 2000. Case Study: The Synergism of Telecommuting and Office Automation. Sloan Management Review 41 (2), 85-96.

Watad, M.M., Will, P.C., 2003. Telecommuting and Organizational Change: A MiddleManagers' Perspective. Business Process Management J ournal 9 (4), 459-72.

Watson-Manheim, M.B., Chudoba, K.M., Crowston, K., 2012. Perceived Discontinuities and Constructed Continuities in Virtual Work. Information Systems J ournal 22 (1), 29-52.

Wright, P., Oldford, A., 1993. Telecommuting and Employee Effectiveness: Career and Manager. The International J ournal of Career Management 5 (1), 4-10. 


\section{Appendix}

\section{Survey items used for EFA analysis}

Participants were asked to indicate the impact of telework on each item using a five-point scale ranging from "a lot more" (1) to "a lot less" (5).

( 1 =a lot more; 2 =a bit more; 3 =no difference; 4 =a bit less; $5=$ a lot less)

1. Your travel between home and the office

2. Your work related travel

3. Costs relating to your telework activities (home office, broadband connection, etc.)

4. The level of managerial control by others over your work

5. Flexibility in scheduling work

6. The complexity of your work tasks

7. Your capacity to work

8. The regard that others have for your work

9. Your professionalism

10. Your ability to collaborate with others

11. Your capability to get things done in your job

12. The overall quality of your work

13. The time it takes to get things done

14. The number of interruptions you experience when working

15. Your relationship with your work colleagues

16. Collegiality in the workplace

17. Your feelings of personal achievement

18. The number of different work tasks you can undertake

19. Your commitment to the organization

20. The ability to be contacted by work colleagues and/ or clients

21. Work related stress

22. Your workload

23. Status within your organization

24. Time for family and friends

Copyright: (C) 2016 Campbell \& Heales. This is an open-access article distributed under the terms of the Creative Commons Attribution-NonCommercial 3.0 Australia License, which permits non-commercial use, distribution, and reproduction in any medium, provided the original author and AJ IS are credited. 


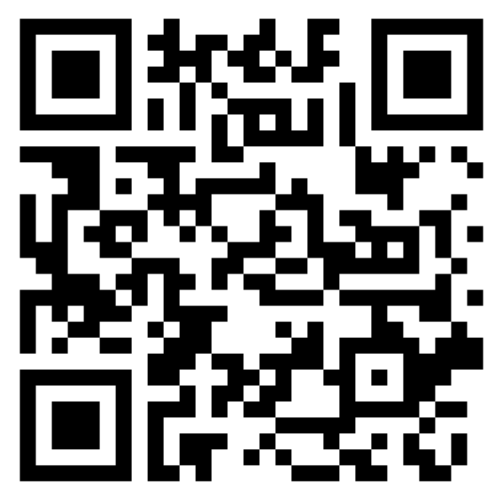

